\title{
The International Student Experience at U.S. Community Colleges at the Onset of the COVID-19 Pandemic
}

\author{
Melissa Whatley \\ School for International Training Graduate Institute \\ Heidi Fischer \\ Old Dominion University
}

\begin{abstract}
This study's purpose is to explore the impact of the COVID-19 pandemic on international students who were studying at U.S. community colleges at the onset of this public health crisis. While previous work has explored the impact of the pandemic on international students generally, we argue that community college international students deserve focused attention due to their potentially marginalized status on their campuses. Using a mixed methods research approach, we analyze survey and interview data provided by community college international educators. Our results speak to two overarching themes: the supports provided to students at the onset of the pandemic (and educators' reasons for providing these specific supports) and the unique impact of the pandemic on community college international students due to their citizenship or residency status. These findings have important implications for community college leaders and international educators as they work with international students during future times of crisis.
\end{abstract}

Keywords: community colleges, COVID-19, mixed methods

The COVID-19 pandemic has had a clear, and unprecedented, impact on international higher education. In the United States, reports from several large international education-focused organizations aimed to capture this impact as the pandemic unfolded. The first of these reports documented early impacts on 
academic student mobility to and from China, the virus's initial epicenter (Institute for International Education [IIE], 2020a). Additional reports have focused on U.S.centered international student mobility in general (IIE, 2020b) and international higher education finance (NAFSA, 2020). The most recent report documented how U.S. institutions' reopening plans addressed important issues around international students and education abroad (IIE, 2020c). Taken together, these reports document significant changes in how higher education institutions (HEIs) serve their international student population. For example, in April 2020, around a third of institutions indicated that they financially supported international students in some way (e.g., airfare, food, rent, tuition, housing refunds) because of the pandemic (NAFSA, 2020). Respondents to another survey noted several virtual instruction challenges for international students, particularly difficulties in engaging with faculty and peers and inability to access online course content (IIE, 2020c).

Indeed, in many cases, the pandemic disproportionately impacted international students studying at U.S. HEIs in comparison with their domestic counterparts. For example, when campuses closed in March 2020 and students were required to return home, home was much further away and more difficult to travel to for many international students, particularly in the context of travel restrictions that aimed to reduce the spread of COVID-19 (Castiello-Gutiérrez \& Tozini, 2020). For international students who chose or were forced to remain in the United States, campus closings meant that students were cut off from important resources that they typically accessed through HEIs, such as dining halls, tutoring centers, and peer networks (Burke, 2020; IIE, 2020b).

While not excluded from recent surveys, community colleges (public, twoyear institutions that grant associate degrees, among other credentials) represent a fraction of the institutions that they include. International students attending these institutions deserve more focused attention. Community colleges are less likely to offer on-campus housing to students, meaning that when classes rapidly transitioned to the online environment, international students were more likely to be disconnected, physically, socially, and emotionally, from campus communities in comparison with international students enrolled at four-year institutions, who were often allowed to remain on campus (e.g., The Well, 2020). Additionally, community colleges received less funding than their four-year counterparts through the CARES Act, passed by U.S. Congress to provide emergency financial relief following the pandemic's onset (St. Amour, 2020). Finally, many community colleges tend to have more recently established infrastructure for international education, thus potentially offering less support for these students in times of crisis (Boggs \& Irwin, 2007; Raby \& Valeau, 2016).

This study's purpose was to explore the impact of the COVID-19 pandemic on international students who were studying at U.S. community colleges at its onset. A focus on international students attending community colleges is important for three reasons. First, these students are likely especially vulnerable to pandemic-related hardships, as just outlined. Of course, these experiences are not necessarily isolated to the community college, and as such, they provide insight into potential challenges faced by international students more generally. Second, because international student enrollment at U.S. community colleges is 
not especially robust (i.e., in 2018-2019, around $8 \%$ of international students in the United States; IIE, 2019), many of these institutions are unlikely to rely financially on international students' tuition payments. As such, insight into these students' pandemic experiences highlight policies and practices that likely differ from those noted in other sectors of U.S. higher education (e.g., Whatley \& Castiello-Gutiérrez, 2021). To this end, this study draws from two theoretical perspectives of international students, placing them in opposition to one another: an economic perspective, which views international students as resources for higher education institutions (e.g., Slaughter \& Rhoades, 2004), and a humanistic perspective, which pushes back on the dehumanization of international students as simply resources, viewing them instead first and foremost as human beings (George Mwangi \& Yao, 2020; Yao \& Viggiano, 2019). Relatedly, a third contribution of this study is that it provides insight into policies and practices that can support international student experiences in a sector that is often marginalized in international education conversations.

To address this study's purpose, we relied on a mixed methods approach, using both survey and interview data from community college international education administrators. While ideally, we would have collected data from international students themselves, the social and political climate in the United States at the time of data collection, Summer 2020, precluded this possibility. That is, U.S. international students comprised an especially vulnerable population during this time, particularly given dramatic changes in the federal government's policies regarding international student visas (St. Amour, 2020; Vital \& Bonds, 2020). Consequently, we felt it was unethical to ask international students to participate in this study. Instead, we use perspectives of international education administrators to provide imperfect insight into students' experiences. This study answers the following research questions:

1. What forms of support did community colleges provide to international students at the onset of the pandemic and why did they choose these specific forms of support?

2. What impact did the pandemic have on community college international students that is unique based on their citizenship and residency status?

Our results speak to the extent to which community college educators were concerned with the pandemic's financial repercussions for their institutions and present the extent to which international students' needs were addressed. Our study has important implications for community college leaders and international educators as they consider the impact of both the COVID-19 pandemic and related crises on international student populations. While this study takes place in the unique context of the COVID-19 pandemic, these implications are broad enough to apply to future contexts and crises. 


\section{THEORETICAL PERSPECTIVES OF INTERNATIONAL STUDENTS}

Recent work examining international students at U.S. HEIs tends to draw theoretically from one of two general perspectives, which we set in contrast with one another to inform this study. The first perspective is decidedly economic and is grounded in resource dependence theory, which suggests that the external resource context determines HEI organizational behavior, including recruitment of international students (Pfeffer \& Salancik, 1978). In this sense, some HEIs may have come to rely on tuition and fee revenue from international students in a context wherein other funding resources have dwindled (Cantwell, 2019). A theory of academic capitalism takes this approach a step further, conceptualizing knowledge, and the students and scholars who possess it, as a commodity that is traded in a global marketplace (Slaughter \& Rhoades, 2004). From this perspective, international student enrollment is akin to a business transaction, wherein credentials, knowledge, and prestige are bought and sold. In the context of the COVID-19 pandemic, such perspectives of international student enrollment have manifested in conversations about the financial future of U.S. HEIs (Associated Press [AP], 2020) and the reliance of HEIs on international student tuition dollars (Whatley \& Castiello-Gutiérrez, 2021).

Although it is likely that some community colleges recruit international students in part or even primarily for financial purposes (and, as we will see later, this perspective was evident in our data), this economically centered perspective may be ill-suited to the study of international student enrollment at many community colleges. Open access lies at the core of the mission of community colleges, meaning that these institutions do not aim to recruit the "best and brightest" students, but rather accept all students who apply, with a commitment to fostering their success (Bailey \& Morest, 2006; Clark, 1960; O’Banion, 2019). An open access philosophy aligns more closely with a second, critical, humanistic theoretical perspective of international students enrolled at U.S. HEIs, which also informs this study. This humanistic approach pushes back on the economic narrative, focusing instead on the experiences of international students, viewing them first as human beings (George Mwangi \& Yao, 2020; Lee \& Rice, 2007; Yao \& Viggiano, 2019). Drawing from critical approaches to the study of international students, researchers have highlighted many negative aspects of the U.S. international student experience, such as encounters with racism and discrimination (e.g., Brown \& Jones, 2013; Stein \& de Andreotti, 2016; Yao et al., 2019), experiences with depression (e.g., Rice et al., 2012), and struggles with self-esteem (e.g., Meegan \& Kashima, 2010), as well as issues surrounding students' feelings of belongingness (e.g., Glass et al., 2015; Glass \& Westmont, 2014). These researchers present international students as individuals rather than economic resources and suggest interventions, practices, and policies that can improve students' experiences. While evidence of a humanistic perspective of international students is likely present in some way at institutions of all types, our focus in this study is on the community college.

Recently, Rose-Redwood and Rose-Redwood (2017) challenged researchers studying international students to focus on sociopolitical aspects of the international student experience, referring to "how the host community perceives and interacts 
with international students, whether international students feel welcomed or threatened [...], and the extent to which the political ambience of a society is hostile to immigrants more generally" (p. v). The COVID-19 pandemic, and the social and political contexts surrounding it, served to underscore already-existing tensions and inequalities in the United States in many arenas, including racial and economic domains (Hardy \& Logan, 2020; Human Rights Watch [HRW], 2020). Our study uncovers tensions surrounding international students that were already present before the COVID-19 pandemic, but that came to the forefront as the health crisis unfolded. Here, we inquire specifically about international students' needs, while also addressing the social and political context surrounding international student experiences. In this sense, we join recent voices pushing back against the dehumanization of U.S. international students in the context of the COVID-19 pandemic (Castiello-Gutiérrez \& Li, 2020).

\section{RELEVANT LITERATURE}

U.S. community colleges are defined as primarily associate degree-granting institutions with an institutional mission that is in service to the local community (Cohen et al., 2013). Community colleges attract a variety of students, from high school graduates in search of affordable credits they can apply toward a university degree, to adults interested in workforce development, to community members enrolled in continuing education programs (González Canché, 2018). These institutions also attract international students, and there is an increasing focus on campus internationalization at community colleges (Raby \& Valeau, 2016).

In the first decade of the 21 st century, U.S. international student enrollment grew by almost 150,000 students. During the same timeframe, community colleges' share of these students increased from 76,834 to 92,838 (IIE, 2019). Campus internationalization in general, and the enrollment of international students, can support the U.S. community college mission to serve the local community (Raby et al., 2014). In fact, the contributions of international students to U.S. community colleges are critical to the mission of preparing domestic students for a globalized workforce (Manns, 2014). Indeed, international students at these institutions contribute to their campuses in numerous ways that are not necessarily financial. These students bring linguistic and cultural diversity to the classroom, provide opportunities for students who have not traveled abroad to interact with someone from another country, and often elevate the average academic achievement at their college (Hagedorn \& Lee, 2005). International students also have higher grade point averages and transfer to four-year institutions at higher rates than their domestic peers (Ghazzawi et al., 2020; Hagedorn \& Lee, 2005).

Limited research explores the backgrounds and enrollment motivations of community college international students. Anayah and Kuk (2015) reported that, like their domestic counterparts, international students often turn to the community college to access higher education. Community colleges are more affordable and frequently provide pathways to universities for international students (Anayah \& Kuk, 2015). Researchers have found that international 
community college students often come from middle-class families, as opposed to the frequently wealthier international students enrolled at universities (Anayah \& Kuk, 2015). Further, international community college students are often language learners with the goal to improve their English proficiency before transferring to university (Anayah \& Kuk, 2015). These characteristics potentially put international community college students in a more vulnerable position at the onset of the COVID-19 pandemic.

\section{International Community College Student Experiences}

Typically, international students as defined in this study reside in the United States on an F-1 visa. These students are required to maintain full-time enrollment and thus spend more time in the classroom and with administrative support staff than U.S. students (Garcia et al., 2019). Consequently, they tend to form stronger relationships with faculty and staff compared with their domestic peers (Garcia et al., 2019; Lau et al., 2018). Such relationships promote academic and social integration, which in turn promote a greater sense of belonging. This greater sense of belonging lends itself to lower withdrawal rates (Garcia et al., 2019; Lau et al., 2018). Further, international community college students make extensive use of on-campus resources, such as computer and skill labs, thus also promoting academic and social success (Lau et al., 2018). When campuses shut down and labs were closed at the onset of the COVID-19 pandemic, this situation suddenly shifted for international students and may have had a detrimental impact on their feelings of belonging and subsequent academic success.

International community college students experience higher levels of psychological challenges than their domestic peers. Not only do these students have to cope with the academic, social, and financial pressures of the college experience (Lau et al., 2018) but they also experience the acculturative stress of adapting to their new host culture (Hansen et al., 2018; Lau et al., 2018). A variety of factors impact levels of acculturative stress, such as country of origin, family support, level of immersion, and, for nonnative speakers, taking courses in English (Hansen et al., 2018). Researchers have noted that international students may need more academic and social support than their domestic peers (Hansen et al., 2018). The COVID-19 pandemic had the potential to amplify stress levels among international students when this support may not have been readily available.

\section{METHOD}

To reach an understanding of how the COVID-19 pandemic impacted the lives of international community college students, after Institutional Review Board approval, we conducted a mixed methods study beginning in June 2020. Our study adopted an explanatory sequential design (Creswell \& Plano Clark, 2018), wherein we first collected and analyzed quantitative data using an online survey instrument. This survey targeted responses from a random sample of individuals on community college campuses who worked directly with international students. 
In the second stage of our research, we collected interview data from volunteer survey participants both to clarify their survey responses and to elicit additional details regarding international students' experiences. To this end, we used qualitative data (interviews) to explain and expand on our mostly quantitative survey findings. While we conducted data collection sequentially, both phases of our study carry equal weight in our presentation and interpretation of findings.

\section{Phase 1: Survey Data Collection}

Our survey asked respondents about the COVID-19 pandemic's impact on international students generally, resources and support for these students, and institutional international education programming. Survey questions were mostly multiple choice (many of which allowed participants to select all applicable responses), as well as some questions that provided space for short written responses.

To elicit survey responses, we identified U.S. community colleges that reported non-U.S. resident student enrollments to the National Center for Education Statistics' Integrated Postsecondary Education Data System in the 2017-2018 academic year. We then randomly selected 300 colleges from this list and searched for contact information for the person or office that we identified as the most likely to work with international students. In the best-case scenario, colleges listed on their websites a person whose title was related to international students or international education, such as Director of International Education. In the absence of an identifiable individual, we searched for contact information associated with an office on campus directly tied to either international students or international education, such as the Office of International Student Life. Finally, if we were unable to identify a specific person or office on campus that was directly tied to international students or international education, we identified the contact information for the person or unit on campus that an international student would contact for enrollment purposes, such as the chief enrollment officer or the Office of Admissions.

\section{Participants}

In total, 17 individuals responded to the survey, representing institutions in 12 states (California, Iowa, Michigan, Missouri, New Jersey, New Mexico, New York, North Carolina, Pennsylvania, Texas, Virginia, and Washington). These institutions enrolled an average of 127 international students during the term impacted by COVID-19, ranging from a low of two students to a high of 1,043. Most survey respondents identified their primary role as either an international student advisor $(n=8)$ and/or working in international recruitment/admissions $(n=8)$. Eight survey respondents also indicated that their primary role was lead international student administrator. Additional roles that these individuals filled included academic advisor $(n=6)$, international student recruiter $(n=5)$, admissions officer $(n=6)$, and a role that included overseeing both international student services and study abroad $(n=6$; participants were allowed to select 
multiple responses for their role). Most of the community colleges that these participants represented had no more than three staff dedicated to international education $(n=11)$. Exceptions included two participants that worked in offices of five to six staff members and another that reported working in an office of 15.

\section{Analysis}

To analyze data elicited through multiple-choice questions, we calculated frequencies for participants' response selections. We read through participants' written responses that elaborated on their multiple-choice selections to extract additional categories not included in our original survey. We also used these written responses to develop our interview protocol.

\section{Phase 2: Interviews}

Our original intent for the second phase of this study was to conduct focus groups with survey participants who volunteered to speak with us further about their students' experiences (Frey \& Fontana, 1991). As only three survey respondents volunteered, almost certainly a result of pandemic-related responsibilities thrust upon international educators, we reorientated our approach to semistructured phenomenological interviews (Frey \& Fontana, 1991) to delve deeper into participants' survey responses. We organized these volunteers into a group of two participants with similar institutional characteristics, who we interviewed in a formal group interview, and one participant, who we interviewed individually (Creswell, 2013; Frey \& Fontana, 1991). Both researchers attended and participated in both semistructured data collection sessions, taking turns asking questions from an interview protocol and taking notes.

Each data collection session began with asking participants to describe March 2020 at their institution considering the pandemic, elaborating especially on aspects of the term that first came to mind. We then asked participants about services provided to international students at the onset of the COVID-19 crisis, which services were most extensively used by international students, and services that they wished they could have provided. Conversations concluded with a question about the future of international education at their institution and advice for future community college administrators and practitioners working with international students in times of crisis. Throughout these interviews, we drew from participants' survey responses to tailor questions to their specific contexts and to probe participants to elaborate further on their responses.

\section{Qualitative Analysis}

Qualitative data analysis was grounded in a social constructivist research paradigm. Social constructivists acknowledge that study participants perceive different realities depending on their individual contexts (Guba, 1990). In this study, all participants were administrators at U.S. community colleges, but their varied professional experiences with international students and their institutions' 
characteristics informed their interview responses. A social constructivist perspective was important for this study because the paradigm acknowledges that truth and meaning are not objective, and are, to a degree, influenced by the participants' interactions with the researchers (Creswell, 2013; Crotty, 1998). Researcher positionality, interview questions, and probes shaped participants' responses (Creswell, 2013). Social constructivists co-construct realities with their participants and aim to present the lived experiences of rich phenomena (Crotty, 1998). Informed by this paradigm, our goal was to understand and reconstruct the participants' realities during the onset of the COVID-19 pandemic, particularly realities surrounding their work with international students (Lincoln \& Guba, 1998).

Each interview was recorded and then transcribed verbatim. We then coded each transcript twice in an iterative manner. First, we applied descriptive codes (Saldaña, 2016), highlighting concepts related to our research questions (Creswell, 2013). Next, we applied axial codes, sorting the descriptive codes into two overarching themes. During this process, we also reorganized the data by refining codes, combining synonyms, and developing a categorical structure for the code set (Saldaña, 2016). In the final step, we selected salient quotes to support our findings.

\section{Researcher Positionality}

Both authors brought with them experiences and perspectives that influenced how they viewed this study's data. Although never an international or community college student herself, the first author has worked with international students at U.S. HEIs for almost 20 years, primarily in English language education roles. Her professional role often involves conducting research to inform community college decision-making, which requires her to interact with individuals in leadership and administrative roles on a regular basis. The second author first enrolled in higher education as an international student from Germany at a U.S. community college. During her associate degree studies, she served as the college's student government president and newsletter editor, getting exposure to community college policies and procedures. Her personal experience at the community college included individualized advising, mentoring, and scholarship support. Her professional experience includes working with international students in an academic advising capacity.

\section{RESULTS}

This section integrates the results of our quantitative and qualitative analyses to provide insight into the significant and varied impact that the COVID-19 pandemic had on U.S. community college international students. Drawing from both survey and interview data together in this section is important, as it improves "the quality of inferences drawn from both the quantitative and qualitative methods" used in our study (Creswell \& Plano Clark, 2018, p. 218). We organize results into two broad categories, following our two research questions: the 
reasons why community colleges provided specific forms of support and the unique impact of the pandemic on international students.

\section{Support for International Students}

When asked about services available to international students during the pandemic, 15 survey respondents indicated that their colleges provided students with online academic advising and the same number provided online tutoring. Twelve participants responded that international students could access online counseling services. Smaller numbers of respondents indicated offering online visa and immigration information $(n=9)$, support of international student groups $(n=$ $5)$, and telehealth appointments $(n=4)$. Four participants also provided written survey responses about other resources provided to international students: a weekly check-in with their principal designated school official, emergency aid grants, a food pantry, and 24/7 telephone access to the international coordinator. Our interview data provided deeper insight into why respondents felt compelled to provide these resources to international students. Specifically, two subthemes spoke to why international students were or should be supported on community college campuses. One of these themes focused particularly on financial contributions of international students while the other took a humanizing perspective.

Perhaps not surprisingly, some interviewees mentioned the revenue that international student tuition dollars brought to their institutions as a reason why these students deserved support. These individuals indicated that this revenue was of particular significance in times when state financial support is waning. Lisa, a director-level international educator at a small community college in a city, explained that some community colleges had been actively building their international programs to make up for the lack of state funding, saying, "There's a lot of budget deficits and a lot of faculty lines that wouldn't exist if it weren't for international students and we're more than happy to take their money to supplement the state cuts." In fact, she elaborated, international students are typically charged out-of-state tuition at community colleges, often more than "two and a half times" in-state rates.

More frequently, however, interviewees described international students through a humanizing lens. Heather, an associate director for international programs at a large suburban community college, shared, "You want to make sure they're all okay and you want to help them all." Especially regarding campus housing policies, administrators emphasized that even international students who could not afford campus housing due to the pandemic needed support. Lisa explained, "They're stuck. What are we going to do? Literally kick them out on the street in a place where they cannot get housing?" Interviewees felt that because international students had been actively recruited to study at their campuses, once the students arrived, they had a moral obligation to take care of them. Lisa, who worked with approximately 25 international students, emphasized, "When you look at these students from poor countries, their families have pooled together all their resources. They've sold land. And to just leave them in the lurch now it's just kind of...I think it's a moral issue." 
The international education administrators we interviewed consistently referenced providing resources that met the needs of international studentsregardless of how difficult they were to provide. At a rural community college with slightly more than 60 international students, international student coordinator Jenn explained that she knew all the students and was able to assist them with individual needs. But even at an institution with more than 1,000 international students, Heather still assisted individual international students in crisis situations. In a case with an international student who may have contracted the coronavirus living with a host family, college administrators provided support through a transition into new accommodations when the host family asked the student to move out. Heather shared, "It was just trying to be a constant support, answering her calls, checking in with her, giving her some resources...because that's the immediate student that's in need. So how are you going to support this student? That's our responsibility."

International students also needed very specific advising support and travel and immigration-related information. All interview participants reported reaching out to their international student population in this capacity, often in an individualized manner. Colleges created websites with COVID-19-related information, sent emails to students, or created lists of resources for international students. Heather, who works at a community college with a large population of international students shared,

We started having these Zoom calls with our F-1 population. For a while it was every week then every other week...We had up-to-date information on a lot of different consulates on what was happening. So we tried to share that information with our F1 population.

Other colleges offered individual Zoom sessions for students. Lisa explained,

We'd help them where we could, or we'd find the place that we could direct them to help and then kind of walk them through. We did a lot of that: 'let's share the screen and figure out this new system'.

\section{Unique Impact on International Students}

A second broad theme in our data highlighted pandemic-related uncertainties related to international travel, finances, housing, and psychosocial support that appeared to be either specific to or more acute for international students.

\section{International Travel}

One issue for international students that emerged in our interview data was international travel. At the onset of the COVID-19 pandemic, some international students experienced uncertainty about their ability to return home. Information that staff provided to international students included the recommendation to contact consulates about travel status and encouragement to be "comfortable with uncertainty." College staff advised students not to travel for spring break outside the country. Other students considered leaving the United States permanently. 
Jenn shared, "I would have [international] students that one day would say 'I'll stay' and then the next day would say 'no, I decided to go home because my mom and dad want me to come home'." Some international students who tried to return home were faced with canceled flights and were ultimately unable to leave the United States. Jenn further explained that some international students "couldn't get home or were afraid to go home because they wouldn't be able to come back." Other international students experienced challenges because of their inability to return home for financial reasons.

\section{Finances}

The pandemic impacted students' finances beyond travel expenses. In our quantitative survey data, seven respondents indicated that international students lost on-campus employment due to the pandemic. These employment opportunities are especially important for international students who supplement personal savings with on-campus employment to pay for everyday living expenses. As interviewee Jenn stated, "There are students who were working on campus and ... when we closed, all those jobs just ended." The pandemic financially impacted students' families as well. In our survey, two respondents indicated that sponsors were unable to send financial support to students due to banking closures and delays, while one indicated that students lost financial support from their sponsors altogether. Survey respondents $(n=2)$ also indicated that students' families lost employment, meaning that they could no longer afford to send money to students.

This financial impact had a direct effect on students' ability to purchase food, to remain in safe accommodations, and to access the technology to pursue online courses. Interviewee Heather explained, "Food banks and shelters, all of those things ... the need for that support grew exponentially." Interviewees provided multiple examples of tangible financial resources made available to international students. Heather remarked that her college foundation offered emergency grants from private donors that were accessible to international students. Lisa shared that her office partnered with the institution's foundation to piece together funding from different sources to offer international students gift certificates for food.

\section{Housing}

Housing was an additional salient concern that participants indicated in both survey and interview data. Quantitatively, of the community colleges represented in the survey, only six offered on-campus accommodations for international students. Five of these respondents indicated that their institutions allowed international students housed on campus to remain even once campuses closed with one institution requiring a petition process. At least two of the community colleges in our survey reported that international students lived with host families. Written survey responses indicated that on one campus, staff proactively reached out to host families to ensure they felt comfortable continuing to host students, while at the same time beginning conversations with campus housing to prepare 
for temporary on-campus housing needs. Further, in her interview, Heather elaborated,

We called all the host families checking in with them, seeing where they were at, if they're feeling comfortable, seeing if students needed to move into the campus housing. Arranging campus housing to say 'okay, how do we prepare campus housing, what are the needs there if stuff goes under quarantine'.

\section{Psychosocial Support Needs}

A final way in which international students were impacted at the onset of the COVID-19 pandemic involved a need for additional psychosocial support. This subtheme did not emerge in our survey data but appeared consistently in our interviews. Administrators remarked that they thought international students felt more stress due to the pandemic than their domestic counterparts and that they worried more about their families in their home countries. Study participants felt that mental health resources were crucial for international students on their campuses, although many campuses did not offer these services. Even though Lisa's college offered mental health resources, she worried about international students" "willingness to seek [them out] and [the institution's] ability to respond to what they need in a culturally responsive way."

\section{DISCUSSION}

This study provides insight into the experiences of international students enrolled at U.S. community colleges at the onset of the COVID-19 pandemic. In this sense, it responds to Rose-Redwood and Rose-Redwood (2017)'s call for a greater focus on the social and political aspects of the international student experience. While international students, in general, have been an especially vulnerable population during this public health crisis, those enrolled at community colleges may have been particularly impacted due to their low enrollment numbers and the marginalized status of international education at many community colleges (Boggs \& Irwin, 2007; IIE, 2019; Raby \& Valeau, 2016; St. Amour, 2020; Vital \& Bonds, 2020). Our results speak to both the numerous ways in which community college leaders provided support for these students at the beginning of the pandemic and the unique problems that international students experienced. Related to this first point, the sense of advocacy that emerged in our interview data was striking. Importantly, while our participants were certainly aware of the economic implications of international student enrollment at their institutions, they leveraged this knowledge to advocate for why resources should be provided to this population, presenting it as institutions' moral obligation to students who had sacrificed so much to enroll. While the most frequently offered resources included online resources, such as advising, tutoring, and counseling, as indicated in our survey data, our interviewees spoke to more nuanced forms of assistance, such as help with pandemic-related host family issues, that go above and beyond basic support. In this sense, our results point to the human side of the international 
student experience at U.S. community colleges. The administrators who participated in this research consistently spoke of students as individuals with specific needs.

Our results also speak to issues that were either unique to or more acute for international students as the COVID-19 pandemic began. Several themes that emerged from our data in this regard included international travel, finances, housing, and psychosocial support. International travel emerged as particularly salient, and administrators consistently came back to issues surrounding students' ability to return home, return stateside if they were abroad, and the financial costs associated with an unplanned return to an international home. Financially, students were also impacted in that they lost employment and allowances from their families or other sponsors. Housing was an additional issue for international students who, if on- or near-campus housing closed (or if host families requested that they leave), often did not have anywhere to go. Finally, services such as psychosocial support took on additional salience for international students. Community college international educators found themselves attempting to address these needs in numerous creative ways. It was in addressing these needs that community college educators perhaps addressed the open access core of their institutions most directly (Bailey \& Morest, 2006; Clark, 1960; O’Banion, 2019). That is, open access not only reflects an openness to student enrollment, regardless of background or academic history, but also the provision of supports for student success (O'Banion, 2019). In the case of the COVID-19 pandemic, the necessary supports international students needed shifted substantially and, in many cases, became more salient. Our study participants provided a wide array of examples of how community college international educators supported international students during a time of significant public health, economic, and social crisis.

\section{Implications for Community College Leaders and International Educators}

The results of our study have clear implications for community college leaders who have international students studying on their campuses as well as the international educators who work directly with these students. While COVID-19 presents a unique situation for international education, lessons learned during this pandemic can be applied to future crises to direct decision-making and guide action. The community college educators who participated in this study provide a useful frame for understanding advocacy for international students, appealing to both the financial implications of international student enrollment as well as the human side of working with students.

More specific strategies for supporting international students speak to resources that students need, perhaps more acutely, during a crisis. Financially, colleges may find it useful to search for creative ways to provide students with scholarships or reductions in the cost of enrollment-particularly for international students who lose employment or sponsorship. Participants in our study reported that they combined funds from a variety of sources to provide emergency aid. 
Having a plan and structure in place to secure these funds should the need arise is an essential component of any college's emergency preparedness plan moving forward. A similar principle applies to housing for international students. In having a plan in place, such as negotiating short-term emergency housing agreements with apartment complexes or even nearby hotels, administrators and educators avoid many of the uncertainties that they and their students experienced at the onset of COVID-19. Finally, our results pointed to substantial collaboration with local community resources to assist in addressing international students' needs. Exploring potential collaborations with local emergency food banks and mental health support services early can avoid future confusion and stress.

\section{Limitations}

One major limitation of this study is that while the aim of our research was to better understand how the COVID-19 pandemic impacted the lives of international community college students, our data came from community college educators who work closely with these students. Certainly, these individuals were able to provide some insight into students' experiences. However, it would be naive to think that their perspectives are an entirely accurate representation of students' experiences. While we originally planned to collect data from both community college administrators and students for this study, the uncertain legal and social circumstances of students during our data collection precluded their inclusion. Future work is needed to explore the perspectives and experiences of international community college students themselves during COVID-19. A second limitation is that we were unable to explore students' experiences according to whether they lived in on-campus housing. Living on campus likely fosters a closer connection between the student and the campus community, a connection that would have been disrupted during the pandemic. Finally, we were unable to conduct the second phase of our research as originally intended using a focus-group approach due to low participant volunteerism. However, we feel that the interviews that we conducted provide rich insight into how the pandemic impacted community college international students despite this limitation.

\section{CONCLUSION}

This study provides detailed information regarding the experiences of international students enrolled specifically at U.S. community colleges at the onset of the COVID-19 pandemic. Our results speak to the precariousness of international students enrolled at these institutions and provide insight into how community college administrators supported them. This study has clear implications for how community college leaders can support this particularly vulnerable student population during future crises, expressed most clearly in international educators' sense of advocacy on behalf of their students. 


\section{ACKNOWLEDGEMENT}

We are grateful for feedback from Rosalind Raby on the survey instrument used in this study and for the kind and constructive comments we received from anonymous reviewers and Stacey Bustillos during the review process. All remaining errors are our own.

\section{REFERENCES}

Anayah, B., \& Kuk, L. (2015). The growth of international student enrollment at community colleges and implications. Community College Journal of Research and Practice, 39(12), 1099-1110. https://doi.org/10.1080/10668926.2014. 934409

Associated Press. (2020, April 7). Colleges suffering huge financial blows from pandemic. CBS News. https://www.cbsnews.com/news/coronavirus-pandemiccolleges-suffering-huge-financial-blows-layoffs-closures/

Bailey, T., \& Morest, V. S. (Eds). (2006). Defending the community college equity agenda. The John Hopkins Press.

Boggs, G. R., \& Irwin, J. (2007). What every community college leader needs to know: Building leadership for international education. New Directions for Community Colleges 2007, 138, 25-30. https://doi.org/10.1002/cc.278

Brown, L., \& Jones, I. (2013). Encounters with racism and the international student experience. Studies in Higher Education, 38(7), 1004-1019. https:// doi.org/10.1080/03075079.2011.614940

Burke, L. (12020, April 20). A ghost town. Inside Higher Education. https://www.insidehighered.com/news/2020/04/20/students-campus-talkabout-experience

Cantwell, B. (2019). Are international students cash cows? Examining the relationship between new international undergraduate enrollments and institutional revenue at public colleges and universities in the US. Journal of International Students, 5(4), 512-525. https://doi.org/10.32674/jis.v5i4.412

Castiello-Gutiérrez, S., \& Li, X. (2020). We are more than your paycheck. Journal of International Students, 10(3), i-iv. https://doi.org/10.32674/jis. v10i3.2676

Castiello-Gutiérrez, S., \& Tozini, K. (2020). Universities as global villages: Supporting international students on campus. NAFSA: Trends and Insights. https://www.nafsa.org/sites/default/files/media/document/trends-insightsdecember-2020.pdf

Clark, B. (1960). The cooling-out function in higher education. The American Journal of Sociology, 65(6), 569-576. https://content.apa.org/doi/10.1037/11302-021

Cohen, A. M., Brawer, F. B., \& Kisker, C. B. (2013). The American community college (6th ed.). Jossey-Bass.

Creswell, J. W. (2013). Qualitative inquiry and research design: Choosing among five approaches (3rd ed.). SAGE. 
Creswell, J. W., \& Plano Clark, V. L. (2018). Designing and conducting mixed methods research. (3rd ed.). SAGE.

Crotty, M. (1998). The foundations of social research. Meaning and perspective in the research process. SAGE.

Frey, J. H., \& Fontana, A. (1991). The group interview in social research. The Social Science Journal, 28(2), 175-187. https://doi.org/10.1016/0362-3319(91) 90003-M

Garcia, H. A., Garza, T., \& Yeaton-Hromada, K. (2019). Do we belong? A conceptual model for international students' sense of belonging in community colleges. Journal of International Students, 9(2), 460-487. http:// www.doi.org/ 10.32674/jis.v9i2.669

George Mwangi, C. A., \& Yao, C. W. (2020). US higher education internationalization through an equity-driven lens. In L.W. Perna (Ed.), Higher education: Handbook of theory and research (pp. 1-62). Springer.

Ghazzawi, D., McKinney, L., Horn, C. L., Carales, V., \& Burridge, A. (2020). The road to the baccalaureate. Journal of International Students, 10(2), 420-442. https://doi.org/10.32674/jis.v10i2.339

Glass, C. R., Kociolek, E., Wongtrirat, R., Lynch, R. J., \& Cong, S. (2015). Uneven experiences: The impact of student-faculty interactions on international students' sense of belonging. Journal of International Students, 5(4), 353-367.

Glass, C. R., \& Westmont, C. M. (2014). Comparative effects of belongingness on the academic success and cross-cultural interactions of domestic and international students. International Journal of Intercultural Relations, 38, 106-119. https://doi.org/10.1016/j.ijintrel.2013.04.004

González Canché, M. S. (2018). Reassessing the two-year sector's role in the amelioration of a persistent socioeconomic gap: A proposed analytical framework for the study of community college effects in the big and geocoded data and quasi-experimental era. In M. Paulsen (Ed.), Higher education: Handbook of theory and research (pp. 175-238). Springer.

Guba, E. G. (Ed.). (1990). The paradigm dialog. SAGE.

Hagedorn, L. S., \& Lee, M. (2005). International community college students: The neglected minority? https://files.eric.ed.gov/fulltext/ED490516.pdf

Hansen, H. R., Shneyderman, Y., McNamara, G. S., \& Grace, L. (2018). Acculturative stress and native and U.S. culture immersion of international students at a community college. Journal of International Students, 8(1), 215232. https://doi.org/10.32674/jis.v8i1.161

Hardy, B. L., \& Logan, T. D. (2020). Racial economic inequality amid the COVID19 crisis. The Hamilton Project. https://www.brookings.edu/wp-content/ uploads/2020/08/EA_HardyLogan_LO_8.12.pdf

Human Rights Watch. (2020, June 10). $\bar{U}$ S: $\bar{C}$ COVID-19 disparities reflect structural racism, abuses. https://www.hrw.org/news/2020/06/10/us-covid-19-disparitiesreflect-structural-racism-abuses\#

Institute for International Education. (2019). International student enrollments by institutional type, 1999/00-2018/19. Open doors report on international educational exchange. https:/opendoorsdata.org/data/international-students/ enrollment-by-institutional-type/ 
Institute for International Education. (2020a). COVID-19 effects on U.S. higher education campuses: Academic student mobility to and from China. https://www.iie.org/COVID19-Effects-on-US-Higher-Education-Campuses

Institute for International Education. (2020b). COVID-19 effects on U.S. higher education campuses: From emergency response to planning for future student mobility. https://www.iie.org/Research-and-Insights/Publications/COVID-19Effects-on-US-Higher-Education-Campuses-Report-2

Institute for International Education. (2020c). COVID-19 effects on U.S. higher education campuses: New realities for global student mobility in Summer and Fall 2020. https://www.iie.org/Research-and-Insights/Publications/ COVID-19-Effects-on-US-Higher-Education-Campuses-Report-3

Lau, J., Garza, T., \& Garcia, H. (2018). International students in community colleges: On-campus services used and its affect on sense of belonging. Community College Journal of Research and Practice, 43(2), 109-121. https://doi.org/10.1080/10668926.2017.1419891

Lee, J. J., \& Rice, C. (2007). Welcome to America? International student perceptions of discrimination. Higher Education, 53(3), 381-409.

Lincoln, Y. S., \& Guba, E. G. (1998). Paradigmatic controversies, contradictions, and emerging confluences. In N. K. Denzin \& Y. S. Lincoln (Eds.), The landscape of qualitative research theories and issues (2nd ed., pp. 163-189). SAGE.

Manns, D. (2014). Redefining the role, scope, and mission of community colleges in an international context. Community College Journal of Research and Practice: Community Colleges and Their Internationalization Efforts, 38(8), 705-709. https://doi.org/10.1080/10668926.2014.897079

Meegan, C. K., \& Kashima, E. S. (2010). Emotional and self-esteem consequences of perceiving discrimination against a new identity group. Asian Journal of Social Psychology, 13, 195-201. https://doi.org/10.1111/j.1467-839X. 2010.01316.x

NAFSA. (2020). NAFSA financial impact survey: Summary brief. https:// www.nafsa.org/sites/default/files/media/document/2020-financial-impactsurvey.pdf

O'Banion, T. (Ed.). (2019). 18 Ideas that are transforming the community college world. Rowman \& Littlefield.

Pfeffer, J., \& Salancik, G. R. (1978). The external control of organizations: A resource dependence perspective. Stanford University Press.

Raby, R. L., Rhodes, G. M., \& Biscarra, A. (2014). Community college study abroad: Implications for student success. Community College Journal of Research and Practice, 38(2-3), 174-183. https://doi.org/10.1080/10668926. 2014.851961

Raby, R. L., \& Valeau, E. J. (2016). International education at community colleges: Themes, practices, research, and case studies. Palgrave Macmillian.

Rice, K. G., Choi, C. C., Zhang, Y., Morero, Y. I., \& Anderson, D. (2012). Self-critical perfectionism, acculturative stress, and depression among international students. The Counseling Psychologist, 40(4), 575-600. https://doi.org/ $10.1177 \% 2 \mathrm{~F} 0011000011427061$ 
Rose-Redwood, C., \& Rose-Redwood, R. (2017). Rethinking the politics of the international student experience in the age of Trump. Journal of International Students, 7(3), i-ix. https://doi.org/10.32674/jis.v7i3.201

Saldaña, J. (2016). The coding manual for qualitative researchers (2nd ed.). SAGE.

Slaughter, S., \& Rhoades, G. (2004). Academic capitalism and the new economy: Markets, state, and higher education. Johns Hopkins.

St. Amour, M. (2020, April 23). Federal funding left out some of the most vulnerable. Inside Higher Ed. https:/www.insidehighered.com/news/2020/04/23/ community-colleges-regional-publics-lost-formula-cares-act-funds

Stein, S., \& de Andreotti, V. O. (2016). Cash, competition, or charity: International students and the global imaginary. Higher Education, 72(2), 225-239.

Vital, L. M., \& Bonds, M. D. S. (2020). Identifying and supporting vulnerable campus populations in times of crisis. Diversity Abroad. https:// www. diversitynetwork.org//DIVaPublic/Articles/Article-Items/Identifying\%20 and $\% 20$ Supporting $\% 20$ Vulnerable $\% 20$ Campus $\% 20$ Populations $\% 20$ in $\% 20$ tim es\%20of\%20Crisis\%20Across \%20the\%20Local-Global.aspx

The Well. (2020). Carolina to switch to remote instruction, reduce residential density. https://www.unc.edu/posts/2020/08/17/shift-to-remote/

Whatley, M., \& Castiello-Gutiérrez, S. (2021). Balancing finances, politics, and public health: International student enrollment and reopening plans at US higher education institutions amid the COVID-19 pandemic. C2i Working Paper Series No. 210201. https://collegecrisis.org/wp-content/uploads/2021/02/C2i_WP 210201.pdf

Yao, C. W., George Mwangi, C. A., \& Malaney Brown, V. K. (2019). Exploring the intersection of transnationalism and critical race theory: A critical race analysis of international student experiences in the United States. Race Ethnicity and Education, 22(1), 38-58. https://doi.org/10.1080/13613324. 2018.1497968

Yao, C. W., \& Viggiano, T. (2019). Interest convergence and the commodification of international students and scholars in the United States. Journal Committed to Social Change on Race and Ethnicity, 5(1), 82-109.

MELISSA WHATLEY, $\mathrm{PhD}$, is an assistant professor of International and Global Education in the School for International Training's Graduate Institute. Her major research interests focus on issues of access and equity in U.S. international education, especially in the community college context. Email: melissa.whatley@sit.edu

HEIDI FISCHER, PhD, is a visiting assistant professor in the Department of Educational Foundations and Leadership at Old Dominion University. Her major research interests lie in the area of community college internationalization, education abroad outcomes, and qualitative international education research. Email: hfisc002@odu.edu 